\title{
Research on Young Teachers Training Model Based on Agricultural Characteristics
}

\author{
Shen Dichen \\ Jilin Agricultural University, Jilin, Changchun, 130118 \\ 781911388@qq.com
}

Keywords: universities; agricultural specialties; young teachers; training model

\begin{abstract}
. development is inseparable from young teachers, young teachers in agricultural colleges and universities is the main force of the future development of the university, plays an important role in higher education. Therefore, the strengthening of youth agricultural colleges and universities teacher training colleges has become an important task. According to the current young university teachers problems in agricultural colleges and universities should be from the way moral construction, teaching and research capacity, incentives and other aspects and effectively strengthen the training of young teachers.
\end{abstract}

\section{Introduction}

In recent years, with the rapid development of higher education, a large number of young intellectuals to join the faculty, the university have become a new force. A direct impact on the quality of young teachers to the level of higher education, therefore, we must pay attention to the training of young university teachers to establish a high-quality young teachers.

\section{Emphasis on the significance of Young College Teachers Training}

(1) Related to the development of higher education

Young teachers are the main force in the future development of the university, inherit and carry forward the fine traditions of shoulder, creating an important mission future career, young teachers grow directly affect the success or failure of universities and higher education. Therefore, the strengthening of great significance and importance of university training of young teachers.

(2) In favor of sustainable development of university

Youth is the future of university teachers in the hope of education. Young college teachers' teaching level, to improve the overall standard of teaching schools, colleges and universities to promote the sustainable development of strategic importance. Cultivate a high quality, strong school teachers are required to achieve leapfrog development.

(3) In favor of the growth of individual teachers

Whether the rapid growth of young teachers, have become an important factor restricting the development of universities. Faced with increasing competition, on the one hand, young teachers themselves should continue efforts to quickly adapt to the environment. On the other hand, the university also timely for the effective training of young teachers improves their overall quality.

\section{Currently young university teachers Problems}

(1) Professional ethics and sense of responsibility needs to be strengthened

Teachers' Ethical directly affects the quality of personnel training. Influenced by some unhealthy, some young teachers ideological level is not high, the lack of adequate love and dedication, lack of education of responsibility and mission, to complete the task of teaching content with the lack of the necessary communication with the students.

(2) Lack of experience teaching, teaching effectiveness is not high

Most young teachers due to lack of teaching skills and experience, not to stimulate student interest, teaching is not ideal. There are some young teachers lack the patience, do not follow the teaching 
requires careful preparation, explain the content too general and too dependent on multimedia courseware teaching, imparting knowledge lack of transition is difficult to guarantee the quality of teaching.

(3) Research consciousness, scientific research level is not high

Some young university teachers because there is no systematic research capacity through training, research and awareness is relatively weak. Some teachers engaged in research just to cope with the scientific assessment or job classification. Young teachers lack experience in scientific research, and less able to fight through their own efforts to the research, more difficult to have a big breakthrough in the research, in academic research there is a big challenge.

\section{Proposals to strengthen the training of young university teachers}

(1) Strengthen the moral construction of young teachers

Strengthening Young Teachers College Teachers' Morality is the basis of a long-term project. Young Teachers academic spirit and attitude so subtle influence on students. To hold regular ethics education seminars, young teacher professional ethics forum organized activities for young teachers to fully communicate and learn. Meanwhile, the young teacher professional ethics as an important part of the assessment, by students, colleagues, leading scoring combination of young teachers for evaluation, strict implementation of "morality vote veto."

(2) To guide young teachers to improve teaching ability

Strengthen the training of young teachers teaching ability, to improve the professional quality of young teachers has important significance. First, the establishment of pre-service training mechanisms. Most young teachers of theoretical knowledge and practical ability relative lack of higher education, the school should do to young teachers educational theory, ethics training and other basics. Secondly, the establishment tutor system. Targeted to arrange for young teachers teaching experience rich old teacher as instructor, give full play to the role of the old teacher mentoring, to help them solve the difficulties encountered in teaching. Third, the establishment of teaching supervision system. The establishment of specialized teaching supervision by subject experts team, conduct occasional lectures to help young teachers to actively identify problems, suggest improvements. Fourth, improve teaching inspection system. Young teachers teach for a year after I apply to the colleges, the College organized experts attending church. After acceptance, the certificate issued by the school, for the acceptance of unqualified teachers should make targeted recommendations, and related training.

(3) Improve the level of scientific research of young teachers

Young teachers to strengthen research support, and effectively improve the level of scientific research of young teachers. First, you should regularly conduct training for young teachers scientific research ability, to participate actively in research to create its atmosphere. Secondly, young teachers to increase investment in research funds to support and encourage young teachers to carry out scientific research, to mobilize the enthusiasm of young teachers, to help resolve the difficulties encountered in the research. Third, research guidance declaration, by the research backbone teachers for young teachers to teach research methods and policies. Tilt to young teachers in the university project application, the exercise of the research capacity of young teachers, encouraging them to apply for a higher level of the project.

(4) Pay attention to the continuing education of young teachers

Universities should focus on training young teachers with development potential, create a favorable environment for young teachers' continuing education. First, actively promote youth academic degrees to enhance teacher's purposefully selected outstanding young teachers to apply for doctoral students. Second, actively carry out academic exchanges and refresher training, there are plans to select outstanding young teachers to universities abroad for academic exchanges, study visits school to encourage their participation in high-level conferences, improve academic vision. Third, encourage young teachers to actively participate in social practice. To the young school teachers to enterprises, practice and create favorable conditions, sending young teachers to enterprises, 
institutions testing exercise, teaching research and practical work closely to improve teachers' teaching and research capabilities.

(5) To build long-term incentives

Colleges and universities to establish a viable long-term competition and incentive mechanism to promote outstanding young teachers come to the fore. Create a good atmosphere for fair competition through various forms of measures, such as the implementation of "backbone teachers training program" to carry out the "top ten young teachers" and other types of awards contest, in recognition of outstanding young teachers in teaching and research, the full develop a model role model, so that more young teachers can produce more results in teaching and research, and enhance self-confidence and sense of honor, and actively work to maximize performance.

Universities should be fully aware of the importance of training young teachers to work for the development of young teachers to create a good environment for training young teachers to establish a sound mechanism to maximize promote the comprehensive development of young teachers.

\section{Conclusion}

Young teachers are an important factor in improving the level of university education is an important force colleges of education, scientific research and other aspects to the development of the relationship between the development of higher education, according to the status of young teachers grow through youth development impact of education asked the following factors Recommendation:

(1) to develop targets based on the ability of young teachers. According to the theory of the objectives to develop challenging goals, targets young teachers to meet the province the ability to set difficult goals within the carrying capacity of young teachers, the target is too high will affect the enthusiasm of the young teachers to work, they are very focused on others evaluation of their ability to work, so young teachers to develop goals, you should first consider their personal abilities, try to set the level of difficulty of young teachers through certain research can be done.

(2) to stimulate interest in the work of young teachers guide. Engel has said that interest is the best teacher, management should focus on faculty work to stimulate interest, given different teachers for different youth development opportunities and the development direction, for a man, in a no interest no development on the job Work is meaningless.

(3) meet the young teachers to improve their level of requirements. Results from the survey that continuously improve the quality of young teachers is a demand for knowledge workers, in order to improve the development and individual capacity, the school where young teachers hope to have more opportunities and time to improve their quality. Young teachers to participate in training and education requires a lot of material and time, from the long-term development of the school discipline, the universities arrange for these teaching programs properly, provide favorable conditions for young teachers.

\section{References}

[1] Xu Juan. Young Teachers College Training Research [j]. Wuxi Institute of Commerce and Technology, 2009 (9).

[2] Yang Yun, Liu Fu Gang university mentoring young teachers to implement exploration and thinking [j]. Modern Distance Education, 2011 (9).

[3] Huang Lu Yang, Huan red Elementary Education major professional orientation and training model [J] Continuing Education Research, 2009 (3): 122 124.

[4] He Qizong Teacher education reform and teacher development [M] Beijing: China Social Sciences Press, $2006.4 \sim 6$. 
[5] to create Huang. Maths Teaching good soft environment [J]. Middle school teaching and research, 2000 (8), 13-15.

[6] Consideration of the Construction Liujiu Cheng Primary Education Curriculum System [J] Yangzhou University, 2004 (1): 88-90.

Survey [7] Li status quo under the new Curriculum School Teachers' Professional Quality [J]. Continue Education Research, 2009 (9),: 129 to 132.

[8] Liu Ruiqiong College English teaching quality improvement and self-development strategy analysis [J] Chinese school education, 2010 (9): 69. 